\title{
TRANSFORMASI MANAJEMEN PEMERINTAHAN: KASUS DI PEMERINTAH KOTA BANDUNG
}

\author{
Samugyo Ibnu Redjo \\ Fakultas Ilmu Sosial dan Ilmu Politik Universitas Padjadjaran \\ Jatinangor Sumedang \\ e-mail: samugyo.ir@gmail.com
}

\begin{abstract}
ABSTRAK. Transformasi manajemen Pemerintah Daerah merupakan suatu keniscayaan sebagai akibat dari perubahan paradigma pemerintahan dari lokus memerintah ke lokus pelayanan; tuntutan good governance; tuntutan demokratisasi serta dinamika pembangunan dan perubahan sosial baik dalam lingkup lokal, nasional maupun global. Tuntutan dan dinamika tersebut, memaksa manajemen pemerintah daerah untuk berkreasi dan berinovasi dalam menata kepemerintahan melalaui proses transformasi yang terencana. Proses transformasi pada manajemen pemerintahan di Pemerintah Kota Bandung pada prinsipnya telah dilakukan. Hal itu terlihat dari perubahan visi dan struktur organisasi pemerintah daerah yang lebih sesuai dengan kebutuhan daerah. Namun, transformasi manajemen pemerintahan tersebut masih belum optimal karena belum berubahnya orientasi kinerja ke arah pencapaian prestasi serta masih adanya ketergantungan bawahan kepada atasan. Akibatnya, kinerja manajemen pemerintahan Daerah dalam memenuhi tuntutan pelayanan publik yang didasari atas kewajaran, keadilan dan efektivitas belum terwujud.
\end{abstract}

Kata kunci: transformasi, manajemen pemerintahan

\section{TRANSFORMATION IN GOVERNMENT MANAGEMENT: A CASE STUDY IN THE CITY GOVERNMENT BANDUNG}

ABSTRACT. Management transformation of local government as the effect of the changing in government paradigm from locus of governing to locus of serving,- the demand of good governance; the demand of democratization and the dynamic of development and changing wether in social, local, and also international scope. Those demand and dynamic force management of government, meaning local government, to create and inovate in order to arranging the government through planned transformation process. Transformation process to governance management of Bandung principally was done. It was shown from the changing of vision and governance structure. Although, the achievement of this process is not yet optimized due to the stagnancy of performance orientation toward achievement-based and the dependency of employee to employer. The impact is, 
local management performance to deliver public services based on fairness, equity, and effectiveness is not yet realized.

Key words: transformation, government management

\section{PENDAHULUAN}

Manajemen pemerintahan di daerah, sebagaimana tuntutan Undang-undang (UU) tentang Pemerintahan Daerah seyogyanya ditransformasikan sejalan dengan tuntutan globalisasi. Hal itu berarti pola-pola, manajemen tradisional feodal yang selama ini dijalankan diganti dengan pola manajemen pemerintahan modern yang demokratis sebagai implementasi nilai-nilai global. Apalagi jika dihubungkan dengan tuntutan UU No. 32 Tahun 2004 tentang Pemerintahan Daerah, khususnya pasal 21, 22 dan 23 yang memberikan hak penuh kepada daerah untuk menyelenggarakan dan memaksimalkan pengelolaan otonomi daerahnya, serta perbedaan substansial antara UU sebelumnya dengan UU ini dalam hal pemilihan Kepala Daerah dan wakilnya.

Pentingnya transformasi tersebut, karena implementasi manajemen pemerintahan di Daerah tidak dapat dilepaskan dari kepolitikan (sistem politik) global dan nasional. Sebagai suatu proses pembangunan politik, transformasi manajemen pemerintahan di daerah berkaitan dengan sejarah sistem Pemerintahan Daerah yang selama ini cenderung bergerak antara politik sentralisasi dan politik desentralisasi, sebagai contoh adalah perubahan dari UU No 5. Tahun 1974 ke UU No. 22 Tahun 1999 tentang pemerintahan di Daerah. UU No. 5 Tahun 1974 yang semula bernuansa pembaharuan sebagaimana tuntutan yang berkembang sejak tahun 1966, dalam implementasi selanjutnya menjadi sangat sentralistis sebagaimana tuntutan politik demokrasi Pancasila melalui dua pendekatannya, yaitu pendekatan keamanan dan pendekatan kesejahteraan. Fenomena ini berubah ketika diberlakukannya UU No. 22 Tahun 1999 tentang Pemerintahan Daerah, DPRD sebagai lembaga representasi rakyat daerah memilih langsung Kepala Daerahnya tanpa ada pengaruh Pusat. Pemberlakuan otonomi daerah pada Daerah Kota dan Kabupaten sebagaimana diatur dalam UU No 22 Tahun 1999 ini memberikan nuansa demokrasi yang relatif lebih partisipatif, dengan kata lain terjadi proses demokratisasi di daerah khususnya dalam pemilihan Kepala Daerah yang tidak ditemukan pada periode pemilihan Kepala Daerah sebelumnya. Hal ini dapat dilihat pada kasus pemilihan Kepala Daerah (PILKADA), tampak terjadi proses "transformasi" dari model PILKADA yang mengikuti kehendak Pusat ke model PILKADA yang "murni" kehendak rakyat Daerah melalui DPRD.

Gejala transformasi manajemen pemerintahan daerah menjadi menarik untuk diteliti di Kota Bandung karena kota ini menghadapi tantangan yang kompleks. Sebagai ibukota provinsi yang merupakan wilayah "penyangga" ibukota, Kota Bandung memiliki keterkaitan politik pemerintahan yang sangat kuat dengan Jakarta, bahkan dapat dikatakan Bandung merupakan 'etalase' politik nasional. Di 
sisi lain, Bandung juga dikenal sebagai kota konvensi yang berhubungan dengan dunia global. Bandung sebagaimana daerah perkotaan lainnya lebih banyak dihadapkan pada persoalan perkotaan, seperti urbanisasi yang berdampak pada tumbuh kembangnya pedagang kaki lima (PKL), pada keterbatasan lahan pemukiman dan lahan hijau, kemacetan lalu lintas, masalah-masalah lingkungan, pelayanan publik serta hubungan antara pemerintah dengan warga kota yang ujungnya pada pelayanan publik serta berbagai alasan lainnya. Keseluruhan aspek di atas merupakan tantangan-tantangan yang memerlukan penanganan dari sisi manajerial pemerintahan daerah, sehingga transformasi manajemen pemerintahan menjadi suatu keniscayaan agar Kota Bandung dapat menyelesaikan tantangantantangan tersebut dengan pendekatan yang lebih responsif dan inovatif. Dalam tulisan ini, akan dibahas mengenai bagaimana proses transformasi manajemen pemerintahan yang dilaksanakan oleh Pemerintah Kota Bandung.

\section{METODE}

Penelitian ini berfokus pada tindakan individu-individu birokrasi yang memegang jabatan publik, sehingga sikap-sikap subjektivitas akan lebih mendominasi pola pikirnya. Fokus penelitian ini relatif akan sulit untuk didekati dengan pendekatan kuantitatif. Karena itu, metode penelitian yang digunakan untuk menganalisis proses transformasi manajemen pemerintahan di Pemerintah Kota Bandung adalah metode penelitian deskriptif dengan pendekatan kualitatif yang diasumsikan lebih dapat menggali informasi yang diperlukan secara lebih mendalam dan terfokus.

Metode penelitian deskriptif-kualitatif tersebut diterapkan melalui langkahlangkah penelitian sebagai berikut:

1. Orientasi awal, guna mengumpulkan data yang berhubungan, informasi kepustakaan dan dokumentasi serta wawancara umum guna menggali berbagai masalah yang berkaitan dengan objek penelitian. Dari data awal yang diperoleh kemudian disusun dalam kriteria spesifik yang dapat diperdalam atau dilanjutkan pada penguraian-penguraian data yang kemudian dilanjutkan pada langkah penelitian selanjutnya.

2. Langkah eksplorasi yang merupakan tindak lanjutan penyempurnaan data yang didapat melalui pendalaman terhadap berbagai data yang masuk kriteria dan menjadi fokus penelitian dengan cara wawancara terstruktur dengan pihak-pihak yang dianggap memahami, menyelenggarakan Focus Group Discussion (FGD) dan cross check terhadap berbagai data yang telah dihimpun dengan pihak-pihak yang berhubungan dengan data yang didapat.

3. Penuangan informasi yang diperoleh melalui pengamatan, wawancara, FGD, yang telah dilakukan dari langkah awal kedalam bentuk laporan penelitian awal dengan data yang telah dikonfirmasikan kepada informan.

Sesuai dengan fokus penelitian, data kualitatif yang ada merupakan data 
yang menggambarkan gejala-gejala yang terjadi di masa lalu sebagai serangkaian peristiwa yang tidak dapat berdiri sendiri, yaitu kepemimpinan walikota sebelumnya, yaitu periode Aa Tarmana (1998-2003) sebagai Walikota. Diambilnya periode ini diperkirakan akan dapat lebih menggambarkan proses transformasi manajemen pemerintahan Kota sekarang.

Informan penelitian adalah Walikota dan Kepala Badan Perencanaan Pembangunan Daerah (BAPPEDA). Diskusi dan dialog juga dilakukan dengan Kepala Badan Pengawasan Daerah (BAWASDA), Kepala Dinas Pendapatan Daerah (DISPENDA), Kepala Dinas Pekerjaan Umum (DPU), Kepala Dinas Tata Kota (DTK), Kepala Dinas Informasi dan Komunikasi (DISINKOM) serta Kepala Dinas Pariwisata, Kepala Kantor Pelayanan Satu Atap (YANTAP). Di luar pemerintahan Kota, wawancara juga dilakukan pada Kamar Dagang dan Industri (KADIN) Kota, beberapa LSM, dan sesepuh Kota antara lain mantan walikota Wahyu Hamijaya dan Aa Tarmana serta sesepuh Kota yang dipandang tepat lainnya. Dialog juga dilakukan pada beberapa anggota DPRD Kota yang dipandang memiliki kapasitas untuk menjawab atau kompeten dalam pembahasan aktifitas transformasi di Kota Bandung. Dialog dan diskusi tersebut dilakukan melalui forum focus group discussion (FGD).

\section{HASIL DAN PEMBAHASAN}

Perubahan Visi Kota Bandung sebagaimana dituangkan pada Rencana dan Strategi (RENSTRA) yang telah menjadi Peraturan Daerah dari yang semula Bandung Kota Jasa yang "Genah, Merenah tur Tumaninah (GMT)" ke Bandung sebagai Kota Jasa yang "BERMARTABAT" yang merupakan singkatan dari Bersih, Makmur, Taat dan Bersahabat. Kedua visi ini terbentuk melalui suatu mekanisme yang berbeda, walaupun kemudian dibuat dalam bentuk Pola Dasar oleh Bappeda dan Renstra oleh Bappeda dibantu oleh tim ahli untuk membahasnya.

Pergeseran ini bisa dikatakan sebagai hal yang positif karena terfokusnya arah kebijakan akan lebih memudahkan dinas, badan, dan lembaga untuk menyusun program kerja yang mengarah pada satu tujuan. Renstra Kota seharusnya dijabarkan lebih lanjut dalam Renstra Dinas yang berupa Rencana Kerja Pemerintah (RKP). RKP memegang peranan yang sangat penting karena akan menjadi rantai penyambung dari rangkaian pembangunan Kota. RKP merupakan dokumen perencanaan teknis dan operasional yang dapat memberikan dasar guna menentukan arah kebijakan dan program dalam pelaksanaan pembangunan daerah. Ruang lingkup program yang termuat dalam RKP hanya meliputi program pembangunan yang dibiayai oleh APBD Kota Bandung, sedangkan program pembangunan yang dibiayai oleh sumber-sumber lain akan dipertanggungjawabkan oleh walikota melalui mekanisme yang berbeda. Materi pokok RKP adalah pokok-pokok kebijaksanaan Pemerintah Kota Bandung selama periode satu tahun anggaran yang dijabarkan dalam bentuk kebijakan, indikasi keberhasilan, indikasi dan sumber pembiayaan untuk dilaksanakan pada tahun tersebut. Ketersediaan indikasi keberhasilan dan kejelasan sumber pembiayaan 
menjadi salah satu tolok ukur transparansi dan akuntabilitas dalam manajemen pemerintahan daerah.

Upaya perubahan struktur ke arah yang lebih baik sesuai dengan tuntutan masyarakat di era Otonomi Daerah ini dilakukan walikota Bandung periode 2004 2008 dengan mengubah pola struktur dan hubungan kerja internal pemerintah Kota Bandung. Perkiraan kebutuhan aparat birokrasi dari segi struktur dan komposisi disusun sesuai dengan ketentuan dalam PP No. 8 Tahun 2003 tentang Pedoman Organisasi Perangkat Daerah. Efisiensi penyelenggaraan pemerintahan sesungguhnya adalah terselenggaranya pelayanan kepada masyarakat sebagaimana mestinya oleh aparatur birokrasi dalam suatu jaringan kelembagaan yang rasional, yang akan dapat menjawab tantangan pelayanan masyarakat dalam penyelenggaraan otonomi daerah.

Oleh karena kelembagaan pemerintahan masing-masing daerah bisa tidak sama antara satu dengan yang lainnya dan ini tergantung kepada kekhasan dan keberagaman daerah serta potensi masyarakat lokal. Selain itu kemampuan daerah, baik dari segi keuangan maupun sumber daya manusianya, terkait dalam penataan kelembagaan ini Karena penataan kelembagaan adalah penataan sumber daya aparatur pula yang akan menjalankan lembaga tersebut, dan kemampuan pembiayannya untuk melaksanakan fungsi-fungsi yang menjadi tugas dan tanggungjawabnya. Kemampuan keuangan daerah dalam penyelenggaraan otonomi menurut UU No. 22 Tahun 1999, sebagian besar ditopang dengan perimbangan keuangan dengan pemerintah pusat, melalui pelaksanaan UU No. 25 Tahun 1999 tentang perimbangan keuangan antara pemerintah puat dan daerah. Tetapi hal tersebut tentunya juga harus diimbangi dengan kemampuan daerah untuk menggali potensi pendapatan yang ada di wilayahnya sendiri dengan melalui upaya pengembangan kemampuan ekonomi rakyat, pengembangan usaha sektor riil, dan pembinaan upaya kerjasama antar daerah dan pihak lain dalam rangka pengembangan potensi ekonomi.

Perubahan UU No. 22 Tahun 1999 menjadi UU No. 32 Tahun 2004 dan PP No. 8 Tahun 2003 menjadi PP No. 41 Tahun 2007 mengubah pula aturan main dalam penataan organisasi perangkat daerah. Kesan sentralistik yang terkandung dalam PP No. 8 Tahun 2003 memang tidak sepenuhnya hilang dalam PP yang baru, tapi peluang bagi daerah untuk menyesuaikan struktur organisasi perangkat daerahnya dengan potensi daerah menjadi lebih besar dalam PP yang baru. Peluang ini sebenarnya dapat dimanfaatkan oleh daerah untuk menerapkan empat fase transformasi manajemen pemerintahan dengan lebih leluasa, mulai dari pembaharuan visi (reframing), penataan struktur (restructuring), penyusunan kerangka prioritas pemerintahan, hal ini berkait dengan target dan tujuan pemerintahan (re-vitalizaton) dan pembaharuan tata kelola pemerintahan secara sistemik (re-newal) (Gouillart dan Kelly, 1995 : 1-14).

Secara ekologis, pemerintah daerah kota Bandung tidak berdiri sendiri, karena 
ia ada dalam kesatuan jaringan yang sistemik dengan bagian-bagian penting pendukung dan potensi Kota, maupun dalam hubungannya dengan pemerintah lebih atasnya. Oleh sebab itu pilihan pembangunan dan hasil yang didapat tidak dapat dilepaskan dari potensi-potensi pendukungnya tidak terkecuali dalam mewujudkan good governance. Dalam mewujudkan good governance di daerah, pemerintah daerah merupakan suatu sistem yang harus memperhatikan sistemsistem lainnya yang ada di sekitarnya. Pemerintah daerah dalam melaksanakan pemerintahan, pembangunan dan pelayanan publik akan mempengaruhi dan dipengaruhi oleh sistem-sistem di sekitarnya.

Semua sistem memiliki peranan yang penting dalam mempengaruhi dan dipengaruhi oleh pemerintah daerah. Dalam era perkembangan teknologi dan informasi, proses interaksi ini bisa semakin cepat, karena dunia seakan tanpa batas. Akses teknologi dan informasi sangat penting bagi pemerintah daerah, untuk meningkatkan kinerja dalam pelayanan dan pembangunan. Dengan informasi dan teknologi, pemerintah daerah dapat merespon informasi, tuntutan dan keinginan masyarakat secara cepat dan tepat serta pemerintah daerah dapat mensosialisaikan program kepada masyarakat sehingga masyarakat dapat ikut serta dan merasa terlibat dalam program tersebut, misalnya dengan menggunakan tekhnologi media masa, komputer, telekomunikasi dan internet.

Pemerintah daerah dituntut memiliki daya adaptasi yang cepat dan tepat, sehingga program yang dilaksanakan sesuai dengan lingkungan sekitarnya, baik lingkungan mikro maupun lingkungan makro. Dengan kemampuan adaptasi ini jugalah, pemerintah daerah dapat melakukan evaluasi secara cepat tentang kesesuaian program yang sedang dilaksanakan, sehingga kendala dan rintangan yang dihadapi dalam pelaksanaan program dapat diatasi sedini mungkin, sebelum program dilaksanakan, ketika program dilaksanakan dan setelah program dilaksanakan.

Hubungan kekuasaan internal pemerintah Kota pada dua kepemimpinan Walikota. Bandung menunjukkan perbedaan gaya kepemimpinan, hal ini disebabkan oleh latarbelakang keduanya yang berbeda. Jika walikota periode 1998-2003 dilatarbelakangi oleh kepemimpinan militer, sementara walikota periode 2003-2008 seorang PNS murni yang tentunya dibesarkan dalam birokrasi pemerintahan Kota. Gaya kepemimpinan pemerintahan mereka tentu berbeda, dalam konteks ini tentunya tuntutan akan pola kepemimpinan pemerintahan yang mendahulukan kepentingan rakyat menjadi tuntutan utama.

Tuntutan terhadap transformasi kepemimpinan pemerintahan ini sesungguhnya bukan merupakan fenomena yang baru pada pemerintahan Kota, keinginan tersebut dimulai dari pergantian walikota tahun 1998. Hal ini ditandai dengan banyaknya calon-calon sipil yang ikut berkompetisi memperebutkan jabatan walikota, apalagi pada tahun 2003, kaum wanitapun pada saat itu memberanikan diri ikut mencalonkan sebagai walikota. Indikasi ini menunjukkan terjadinya perubahan sosial di masyarakat, sehubungan dengan semakin meningkatnya pendidikan masyarakat s0erta semakin beragamnya kebutuhan 
rakyat. Pada tataran ini sangat tampak kebutuhan rakyat akan transformasi kepemimpinan pemerintahan yang lebih adaptif dengan tuntutan perubahan tersebut.

Budaya birokrasi Pemerintah Kota Bandung masih belum berubah, sebagaimana diindikasikan dari beberapa kecenderungan sebagaimana tabel berikut.

\section{Tabel 1. Karakteristik Budaya Birokrasi Pemerintah Kota Bandung}

Hubungan birokrasi dengan jajaran Dominasi, patrimonial, ewuh pakewuh birokrasi lain

\begin{tabular}{ll}
\hline Hubungan birokrasi daerah dengan & Dominasi \\
Masyarakat & \\
Mekanisme penilaian kinerja dan & Tidak akuntabel, orientasi pelayanan \\
penetapan standar kerja & tinggi \\
Mekanisme pengawasan & Dominasi dan paternalistik \\
Pola komunikasi atasan-bawahan & Dominasi \\
Pola komunikasi bawahan-atasan & Ewuh-pakewuh(risi) \\
\hline
\end{tabular}

Sumber : BIGS, Asia Foundation, AKATIGA, 2003

Kecenderungan pola perilaku tradisional tersebut disebabkan oleh sejumlah faktor. Pertama, pola hubungan patronase Kedua, Pemerintah Kota merupakan birokrasi pada lapisan yang lebih bawah dari birokrasi Provinsi dan Pusat. Ketiga, proses desentralisasi dan sentralisasi selalu merupakan tarik ulur kekuatan. Keempat, klien baru dapat melepaskan diri dari pola budaya patron-klien jika mereka mampu memperoleh sumber lain yang dapat menjaga kelangsungan hidup mereka. Kelima, perubahan birokrasi juga diduga akan sangat tergantung dari peran para aktor di luar lingkungan birokrasi dalam mengontrol dan mendesak tuntutan perubahan ke arah birokrasi.

Fenomena yang menarik adalah, dalam kasus Kota Bandung, penggemukan birokrasi justru semakin membesar setelah pemberlakuan UU No. 22 Tahun 1999 tentang Pemerintahan Daerah. Pelaksanaan UU tersebut membawa konsekuensi pelimpahan pegawai dari instansi vertikal, baik pusat maupun propinsi, ke dalam lingkungan Pemerintah Kota Bandung. Akibatnya, terjadi penambahan pegawai dari semula 5.867 orang menjadi 25.496 orang. Tapi, bila dikaitkan dengan kinerja pelayanan yang diberikan pemerintah, ternyata kondisinya berbanding terbalik.

Penilaian masyarakat terhadap kinerja Pemerintah Kota Bandung cenderung rendah, khususnya untuk kinerja yang berkaitan dengan pelayanan publik. Hasil penelitian yang dilakukan Bandung Institute for Governance Studies (2002) terhadap kepuasan konsumen pelayanan publik di Kota Bandung misalnya, 
menunjukkan bahwa tingkat kepuasan masyarakat terhadap pelayanan yang diberikan instansi Pemerintah Kota cenderung rendah. Tingkat kepuasan konsumen paling tinggi adalah terhadap jasa layanan SD Negeri $(82,8 \%)$ jasa pelayanan akta kelahiran yang diselenggarakan oleh Dinas Kependudukan (82,6\%) jasa layanan Kartu Tanda, Penduduk yang diselenggarakan oleh Dinas Kependudukan $(81,2 \%)$, jasa layanan SUP Negeri yang diselenggarakan oleh Dinas Pendidikan $(80,7 \%)$, dan jasa pelayanan Puskesmas yang diselenggarakan oleh Dinas Kesehatan (78 \%).

Pimpinan unit kerja atau instansi-instansi pemerintah Kota lainnya belum mampu memilih program pembangunan atas dasar skala prioritas yang telah ditentukan sesuai dengan arah kebijakan yang telah dituangkan kedalam renstra Kota. Sementara sistem target pencapaian telah disusun menjadi prioritas dan evaluasi tahunan, bulanan Berita Mingguan mulai diterapkan, hal itu tampak dari penterjemahan arah kebijakan kedalam langkah-langkah strategis seperti Bandung Cerdas 2008, Bandung Sehat 2007, Bandung Hijau dan Berbunga 2006, Bandung Berprestasi 2008, Bandung Ramah 2007, Bandung Cantik 2006 dan Bandung Religius 2007.

DPRD Kota Bandung yang telah membuka wacana demokrasi seluas-luasnya untuk kandidat walikota dalam prosesnya tidak diikuti oleh kematangan politik kandidat, sehingga terkesan kandidat walikota tersebut hanya mencari popularitas bagi dirinya sendiri. Adanya tim independen yang berasal dari masyarakat yang menilai visi dan program kandidat menilai bahwa pemahaman dan penguasaan masalah serta solusi yang ditawarkan kandidat dipandang tidak memahami masalah perkotaan, akibatnya jawaban kandidat terkesan mengada-ada.

Pemahaman terhadap masalah perkotaan serta pemahaman terhadap aturan pada dasarnya merupakan instrumen mendasar bagi seorang walikota sebagai pemimpin pernerintahan Kota untuk kemudian mampu menterjemahkannya dalam berbagai kebijakan. Dan hal ini, relatif tidak banyak dikuasai kandidat calon, walaupun demikian terdapat beberapa pemikiran dan terobosan barn mengenai penataan Kota, antara lain: bahwa "Bandung harus dilihat dari kacamata metropolitan", "permasalahan Bandung juga harus dilihat sebagai akibat pemikiran yang tidak komprehensif', "koordinasi yang kurang, keterpaduan yang kurang terintegrasi dalam pelaksanaan program" serta beberapa pandangan lainnya.

\section{SIMPULAN DAN SARAN}

Perubahan dalam tata kelola pemerintahan menjadi penting karena pemerintahan adalah ujung tombak yang bertanggung jawab dalam mencapai citacita kesejahteraan. Perubahan dalam ranah politik tidak akan berdampak pada perubahan taraf hidup masyarakat bila tidak dijembatani oleh perubahan dalam manajemen pemerintahan yang mengubah kekuasaan tersebut ke dalam kebijakan-kebijakan yang pro publik. Kewenangan untuk merumuskan, melaksanakan, dan mengawasi kebijakan-kebijakan tersebut adalah ranah pemerintahan, sehingga transformasi pemerintahan pun menjadi keniscayaan agar 
demokratisasi bermakna.

Akan tetapi, di tengah gejolak perubahan politik, transformasi manajemen pemerintahan seolah menjadi agenda yang terlupakan. Arena publik begitu disibukan dengan pertarungan politik, sehingga energi untuk memantau tata kelola pemerintahan seolah habis terserap. Desentralisasi pemerintahan hanya berhenti sebatas janji ketika rotasi kekuasaan akan berlangsung melalui pemilihan lima tahunan, tapi setelah prosesi pelantikan pemimpin politik, janji itu menguap dan praktik pemerintahan kembali pada kebiasaan lama. Business as usual, begitu ungkapan sinis yang mengambarkan betapa birokrasi pemerintahan menjadi sisi tak tersentuh dari agenda perubahan.

Uraian pada bagian-bagian sebelumnya mengungkapkan bahwa transformasi manajemen pemerintahan merupakan proses yang kompleks dan tidak dapat dilepaskan dari komitmen politik. Setiap pemimpin politik memiliki gaya kepemimpinan tersendiri yang akan menentukan karakter manajemen pemerintahan yang dipimpinnya. Di tengah perubahan sosial yang makin dinamis, pemerintah sebagai suatu organisasi dituntut untuk mampu beradaptasi demi mempertahankan eksistensinya, termasuk mempertahankan legitimasinya di mata publik. Kegagalan pemerintah untuk memenuhi kebutuhan masyarakat akan menimbulkan krisis kepercayaan kepada pemerintah, yang dalam jangka panjang menyebabkan pemerintah kehilangan legitimasinya untuk mengelola tertib sosial.

Implikasi jangka panjang inilah yang menyebabkan transformasi manajemen pemerintahan sesungguhnya menjadi agenda yang penting yang semestinya dipersiapkan dengan serius. Transformasi manajemen pemerintahan bukanlah suatu proses yang otomatis, yang akan langsung terjadi ketika sistem berubah. Kasus manajemen pemerintahan Kota Bandung, seperti yang terungkap dalam tulisan ini membuktikan betapa kompleksnya proses transformasi manajemen pemerintahan berlangsung. Dengan menganalisis dua periode kepemimpinan walikota, penulis menunjukkan bahwa transformasi manajemen pemerintahan memerlukan lebih dari sekedar figur pemimpin, tapi juga kapabilitas kepemimpinan yang mampu mengarahkan semua sumber daya organisasi untuk mendukung perubahan tersebut. Artinya, legitimasi politik tidak cukup untuk mendorong transformasi manajemen pemerintahan, karena masih diperlukan perubahan sistem, mekanisme, bahkan budaya dalam organisasi pemerintahan. Karenanya, transformasi manajemen pemerintahan seharusnya menjadi agenda berkelanjutan dari para pemimpin politik.

Proses transformasi manajemen pemerintahan yang meliputi perubahan sebagai jabaran konsep reframing menunjukkan adanya perubahan visi dan misi kota, walaupun perubahan tersebut tidak berdampak pada perubahan prilaku aparat. Proses perubahan struktur sebagai jabaran dari restructuring menunjukkan adanya perubahan, jika dihubungkan dengan besaran jumlah aparat, maka proses transformasi menunjukkan ketimpangan dan ketidakadilan jika dibandingkan 
dengan Daerah Kabupaten dan Kota di luar jawa, juga tatkala dihubungkan dengan demokratisasi dalam penjabaran asas desentralisasi. Ekologi pemerintahan yang merupakan jabaran dari proses revitalization, menunjukkam bahwa proses transformasi berlangsung melalui tindakan-tindakan penyusunan prioritas yang harus diselesaikan. Hubungan kekuasaan yang merupakan jabaran proses "renewal", pada kasus proses transformasi ini pernyataan "kits tidak dapat memotong sejarah " adalah sangat tepat. Pendekatan demokrasi tidak dapat sekali jadi, ia membutuhkan waktu untuk berproses. Keadilan, kewajaran dan efektifitas dalam proses transformasi manajemen pemerintahan relatif belum mampu dilaksanakan dengan memuaskan, setidaknya dapat dilihat dari rasa keadilan dalam pelayanan publik. Hal ini antara lain disebabkan oleh sikap dan prilaku birokrasi dan warga yang minta dilayani, "jika ada koneksi baik hubungan dekat, uang maupun faktor lainnya, maka pelayanan akan lebih mudah didapat, disisi lain pelayanan akan mudah didapat apabila warga yang meminta pelayanan mempermudahnya dengan sogokan".

Berdasarkan simpulan di atas, maka beberapa rekomendasi berikut tampaknya perlu diperhatikan dalam proses transformasi manajemen pemerintahan, yaitu: pertama, proses transformasi manajemen pemerintahan Kota yang baik sebaiknya didukung oleh SOTK yang ramping, suatu bentuk pemerintahan yang memperbanyak fungsi dan disesuaikan dengan bidangnya serta organisasi pemerintahan yang mempunyai struktur yang ramping sesuai dengan visi dan misi yang ingin dicapai seyogyanya diikuti dengan perampingan pegawai, sehingga kebijakan perampingan SOTK berakibat langsung pada efisiensi dan efektivitas pemerintahan. Untuk perampingan pegawai tersebut sebaiknya dilakukan dengan terlebih dahulu menentukan standar kuantitas jumlah pelayanan, sehingga diketahui perbandingan besaran antara jumlah pegawai yang dibutuhkan dengan jumlah penduduk yang dilayani. Melalui besaran perbandingan tersebut, maka dapat diperkirakan berapa sesungguhnya pegawai yang dibutuhkan oleh suatu pemerintah Daerah, sehingga kelebihan pegawai atau pegawai pemerintah yang nganggur dapat dipensiunkan atau disalurkan keberbagai kegiatan lain diluar sektor pemerintahan atau kebadan-badan usaha milik pemerintah

Kedua, membutuhkan political will dari pemerintah maupun anggota manajemen pemerintah Pusat maupun Daerah. Oleh sebab itu, sebaiknya setiap kebijakan pengaturan yang dikeluarkan oleh Pusat seyogyanya diikuti pula dengan strategi lanjutan mengenai pengamanan pelaksanaannya, yang antara lain: (1) menyusun standar kebutuhan struktur pemerintah Daerah yang didasarkan pada basaran jumlah penduduk, sehingga pelayanan dapat dilakukan maksimal untuk masing-masing penduduk; (2) menyusun standar kebutuhan besaran pegawai untuk suatu pelayanan publik tertentu, sehingga pelayanan pemerintahan dapat efektif dan efisien; (3) menyusun standar kebutuhan rakyat untuk suatu pelayanan publik. Di sisi lain proses transformasi juga membutuhkan manajemen pemerintah Daerah yang memiliki kemampuan untu : (1) bersinergi, yaitu kemampuan untuk bekerja secara kolektif bersifat terbuka dan mampu berkoordinasi; (2) memiliki 
kompetensi dibidangnya yang memadai, sehingga dapat memilah mana fungsinya dan mana fungsi pihak lain; (3) memiliki kemampuan untuk menggerakkan bawahan yang disebabkan oleh kepercayaan bawahan kepadanya; (4) memiliki motivasi yang kuat untuk maju, sehingga tidak mudah mengeluh atas tugas yang dibebankan padanya; (5), mampu bekerja mandiri dan tidak bergantung pada kedekatannya dengan walikota serta persyaratan administratif lainnya.

Ketiga, walaupun jabatan kepala Daerah adalah jabatan politik dan bukan jabatan karir, akan tetapi karena ini hakekat pemerintah Daerah adalah organisasi pelayanan publik terdepan, maka penguasaan terhadap manajemen pemerintahan seyogyanya dipersyaratkan bagi calon-calon kepala Daerah yang akan dipilih, di samping persyaratan administratif lainnya.

\section{DAFTAR PUSTAKA}

Bennett, Robert (ed). (1994). Local Government and Market Decentralization: Experiences in Industrialized, Developing, and Former Eastern Bloc Countries. Tokyo, New York, Paris: United Nations University Press.

BPS. (2004). Bandung Dalam Angka 2003. Bapeda Kota Bandung.

Darwin, Muhadjir. (1996). Pengembangan Aparatur Pemerintah Indonesia. Dalam Riza Noer Arfani. Demokrasi Indonesia Kontemporer. Jakarta: Rajawali Press.

Fitzsimmons, James A. dan Mona J. Fitzsimmons. (1994). Service Management for Competitive Advantage. New York: McGraw-Hill Inc.

Gouillart, Francis J. dan James N. Kelly. (1995). Transforming the Organization. New York: McGraw-Hill Inc.

Koehler, Jerry W., Pankowski, Joseph M. (1997). Transformational Leadership in Government. Florida: St. Lucie Press.

Kooiman, Jan (ed). (1993). Modern Governance : New Government-Society Interactions. London, Newbury Park, New Delhi: Sage Publications.

Osborne, David dan Ted Gaebler. (1995). Mewirausahakan Birokrasi (terjemahan). Jakarta: PT Pustaka Binaman Pressindo.

Orborne dan Peter Plastrik. (1997). Banishing Bureaucracy. New York: Addison Wesley Publishing Company. 